\title{
The Effect of Formaldehyde Disinfectant on Compressive Strength of Dental Stone (Type IV)
}

Musab Mohamed Ibrahim BDS

Munther Najeeb Kazanji BDS, MSc(Assist Prof.)

Salwa Hachim Mohammed BSc, MSc,PhD. (Assist Prof.)

\author{
Department of Prosthetic Dentistry \\ College of Dentistry, University of Mosul \\ Department of Prosthetic Dentistry \\ College of Dentistry, University of Mosul \\ Department of Basic Science Department \\ College of Dentistry University of Mosul
}

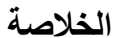

الاهداف:تهدف الدراسة إلى تقييم تأثير (2\%) فورمالديهايد على القوة الانضغاطية للقالب لمادة الحجر السني النوع (IV) وكذللك تقييم تأثيره

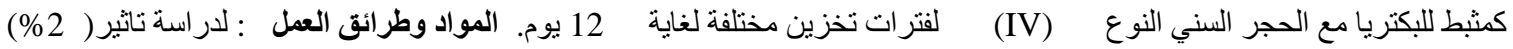

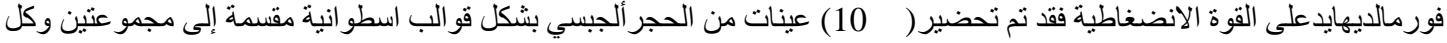

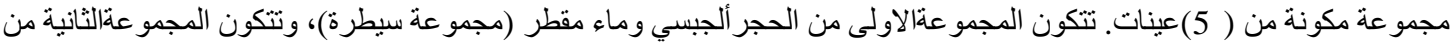

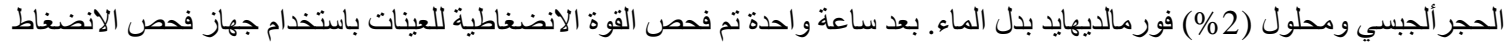

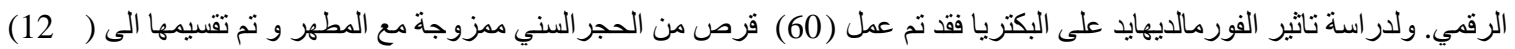

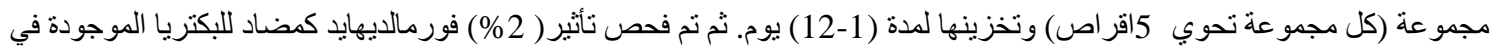

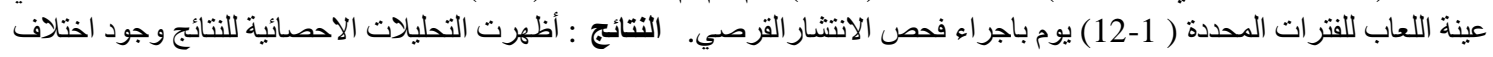

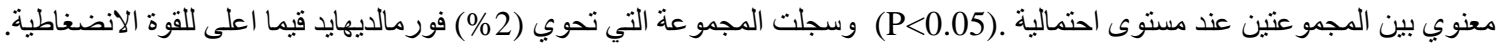

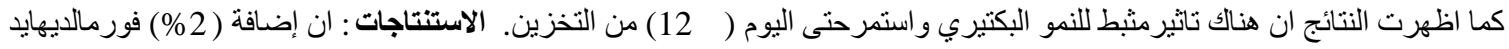
كمادة كيميائية مطهرة وخلطها مع قالب الحجر السني سوف يزيد القوة الانضغاطية مع استمر ار التاثير المثبط للبكتريا حتى اليوم 12.
\end{abstract}

\begin{abstract}
Aims: The purpose of this study is to evaluate the effect of $2 \%$ formaldehyde on compressive strength of dental stone (type IV), and to evaluate its antibacterial effect. Materials and methods: To study the effect of $2 \%$ formaldehyde on compressive strength of dental stone (type IV), ten samples of stone were prepared in cylindrical blocks and divided into two groups, each group contain of (5) samples. First group composed of stone and distilled water as (control group) and the second group composed of stone and (2\%) formaldehyde solution. after (1h) the samples were tested for compressive strength using digital compression machine(ALFA Company, Turkey).To study the bacterial effect of formaldehyde 60 stone discs prepared and mixed with formaldehyde 2\% divided into 12 group (each group consist of 5 discs) and stored for different intervals between 1-12 days, antibacterial effect against salivary sample for each interval day using disc diffusion test. Results: The statistical analysis of data by analysis of t-test reveals significant different in compressive strength between control group and stone-2\% formaldehyde group at $(\mathrm{P}<0.05)$. The result showed that second group which contains $2 \%$ formaldehydehad higher values compared with control group. Also the results showed that the antibacterial effect of stone-formaldehyde discs continued till 12thday. Conclusions: Adding 2\% formaldehyde as chemical disinfectant to dental stone increase the compressive strength in addition of the antibacterial activity of stone - formaldehyde disc continued till 12th day.
\end{abstract}

Key words: Formaldehyde, disinfectant, compressive strength

Ibrahim MM, Kazanji MN, Mohammed SH. The Effect of Formaldehyde Disinfectant on Compressive Strength of Dental Stone (Type IV). Al-Rafidain Dent J. 2016(1): 1-9.

Received: 14/5/2013 Sent to Referees: 19/6/2013 Accepted for Publication: 9/9/2013 


\section{INTRODUCTION}

There are many researches on dental infection control, which have documented a large number of microbes that are retained on impression materials and are viably transferred onto the surface of gypsum casts. Particularly as new materials and techniques are introduced to enhance existing infection control procedures and reduce potential sources of cross-contamination ${ }^{(1,2,3,4) \text {. }}$

Disinfection of the dental cast is one of the manipulation phases of the gypsum material (5). The prevalence of infectious diseases and their harmful effects requires attention to infection control procedures in the dental office and dental laboratory ${ }^{(6)}$.

Formaldehyde presents as bactericidal, sporocidal, virucidal and fungicidal activity, and could be employed also for environments fumigation. The use of formaldehyde is allowed for high level disinfection of critical and non-critical things, such as dialyzer, filters, catheters and laparoscopes ${ }^{(7)}$. Compressive strength of gypsum material is indicative of the ability of the material to resist fracture ${ }^{(5) .}$ The aim of this study to evaluate the release of formaldehyde $2 \%$ at different intervals between 1-12 days as antibacterial when mixed with stone type IV, and the effect of using (2\%) formaldehyde disinfectant as water substitute to dental stone (type IV) on the compressive strength comparing with control group (dental stone type IV mixed with distal water). As impression disinfection is difficult and associated with several problems, attention was directed towards cast disinfection ${ }^{(8)}$. Several methods have been recommended to disinfect dental casts, which include immersion in disinfectant solution, spraying with disinfectant, ad- dition of disinfectant agents in composition of gypsum and incorporation of disinfectants into the gypsum at the time of mixing $(9,10,11,12)$. Studies showed that these methods may affect the physical and mechanical properties of dental stone, such as setting time, compressive strength and dimensional accuracy ${ }^{(11-15) .}$

\section{MATERIAL AND METHODS}

For this study dental stone type IV was used to prepare two groups of samples:

1. Control group: Was prepared by mixing stone with distilled water.

2. Formaldehyde group: Was prepared by mixing stone with $2 \%$ formaldehyde.

$2 \%$ formaldehyde concentration was prepared from (37\%) formaldehyde concentration (original solution) using distilled water. . If less than (3) samples values remain to be averaged, the test shall be repeated. In this study (5) samples were used for each group. One sample failed for each group, the average of remaining samples was calculated ${ }^{(16) .}$ Compressive Strength samples were prepared according to American dental association (ADA) specifications number 25 , which mentioned that the number of samples for testing compressive strength should be (5) specimens and shall be averaged. Ideal average of compressive strength for stone with water is (300 $\pm 50 \mathrm{~kg} / \mathrm{cm} 2)$ so that any sample value departing from the average by more than (15\%) shall be discarded (failure) and the remaining samples values averaged For compressive strength testing cylindrical samples were prepared with dimensions (20 $\mathrm{mm}$ ) width and (40 $\mathrm{mm}$ ) height using metal split mold Figure (1) 


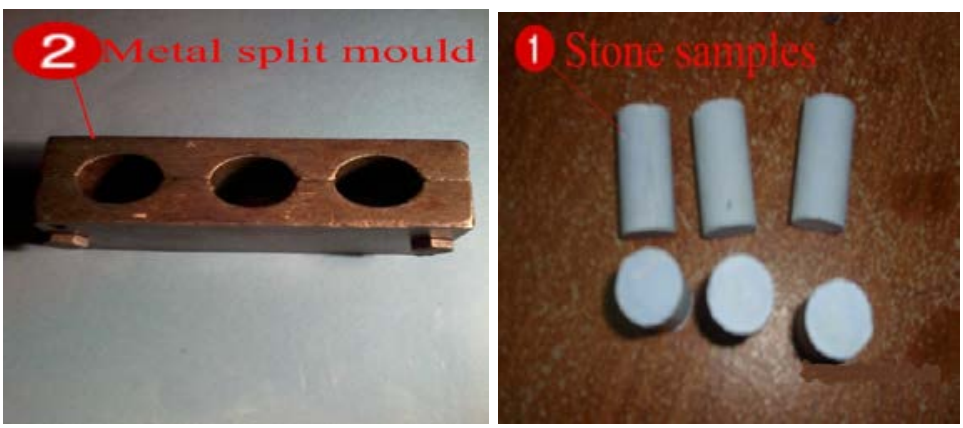

Figure (1): Stone samples for compressive strength test.

1. Control group: Five samples were prepared by mixing 100 gm dental stone with $25 \mathrm{ml}$ distilled water.

2. Formaldehyde group: Five samples were prepared by mixing 100gm dental stone with $25 \mathrm{ml} 2 \%$ formal- dehyde.

3. The stone mixture was prepared by vacuum mixer (Degussa, Multivac 4, Germany) for (45) second as in Figure (2)

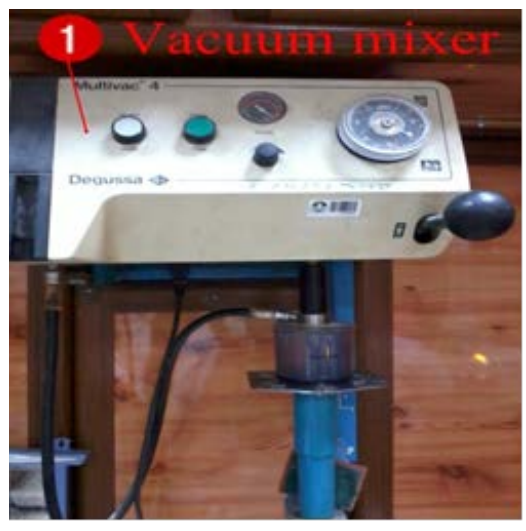

Figure (2):vacuum mixer

and then the mixture was poured in to the metal split mold using a vibrator. Glass slab was put under the metal split mold and another glass slab over the metal split mold to provide flat parallel surfaces which is important for the compressive strength test. 


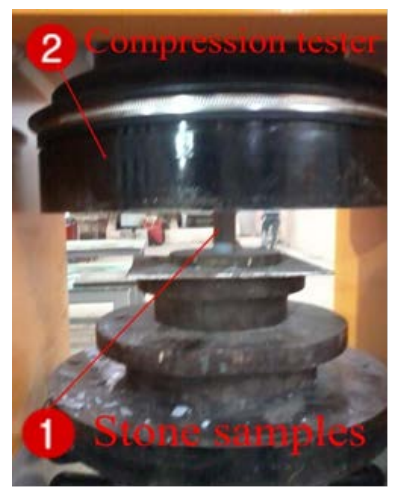

Figure (3):Digital compressive machine

The compression testing machine has digital indicator, the device is electronically and automatically adjusted on the sample and apply a gradual forces in a long time period and the force increases gradually until sample start to crack, the digital indicator record the force in kilo Newton (KN) to get exact force at the moment of fracture using following equations:

\{Compressive strength $=$ forces/area

So that to get $\{\mathrm{kg}$ unit $=12100 / 9.8$ (gravity) $\}$ $=1234.69 \mathrm{~kg}$

Area of cylindrical sample=radius $\wedge 2 \times 3.14\}$

Diameter of sample is (2) $\mathrm{cm}$ so Radius $=1 \mathrm{~cm}$ so area of sample is $1 \wedge 2 \times 3.14$

Finally \{compressive strength $=1234.69 / 3.14=393.21 \mathrm{~kg} / \mathrm{cm} 2\}$
Statistical analysis SPSS (t-test) was used.

For antibacterial assay 60 disc samples were prepared by mixing $2 \%$ formaldehyde with stone type IV. These discs were prepared in $(\approx 6 \mathrm{~mm})$ diameter, divided (5 disc for each day), and stored for different time intervals (1-12) days to evaluate their antibacterial effect at different times of storages. The Brain heart infusion plates were inoculated with saliva as a source of bacteria, and then the discs placed on surface of agar using flame sterilized forceps, the plate incubated at 37oC for 18-24h. The disinfectant will diffuse from the disc into the agar only around the disc. After incubation period area of no growth around the disc "zone of inhibition" were measured to evaluate the effect of formaldehyde on bacteria. Figure (4).

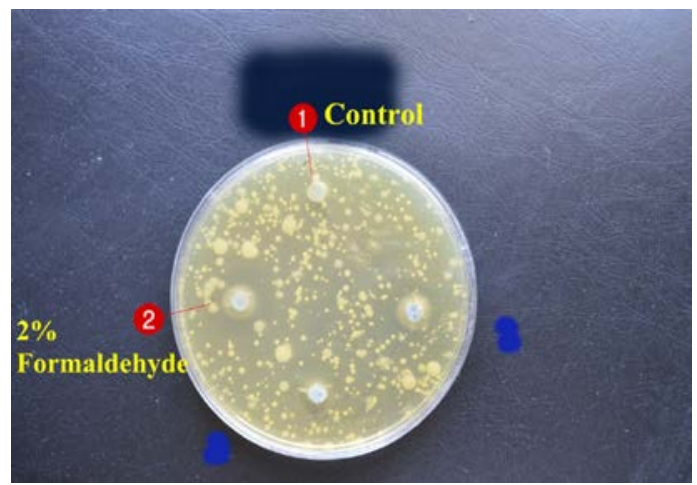

Figure (4):The inhibition "zone of 2\% formaldehyde stone disc comparing with control and other disinfectants 


\section{RESULTS}

Statistical analysis was done using SPSS independent samples t-test to compare between control group (stone with distilled water) and formaldehyde group (stone with $2 \%$ formaldehyde) and the results showed that the mean of compressive strength of the formaldehyde group samples mean=287.915 $\mathrm{kg} / \mathrm{cm} 2$ is significantly higher in value comparing with the mean of control group samples (mean=234.74 kg/cm2) as shown in Table (1)

Table (1): t-test Independent 2 samples of compressive strength results.

\begin{tabular}{llll}
\hline Compressive strength & \multicolumn{4}{l}{ t-test for Equality of Means } \\
& T & Df & P-value \\
Equal variance assumed & -4.985 & 6 & 0.002 \\
\hline
\end{tabular}

and these differences lead to significant differences according to $t$ test at $(\mathrm{P}=0.002)$ which means that second group formalde- hyde is greater in compressive strength with significant difference than control as in Table (2).

Table(2): Descriptive statistical results of compressive strength.

\begin{tabular}{lllll}
\hline Groups & N & Mean & SD & SE \\
Control & 4 & 234.7425 & 18.86174 & 9.43087 \\
Formaldehyde & 4 & 287.78 & 9.879 & 4.939 \\
\hline
\end{tabular}

SE:Standard Error

SD: Standard Deviation

Statistical analysis of antibacterial result was done by using one way ANOVA and Duncan Multiple Analysis Range Test in post hoc. The results shows there are significant differences of all intervals days vs. control disc at $P<0.05$ as in Table (4)

Table (3): ANOVA results among all stone groups.

\begin{tabular}{llllll}
\hline Diameters & Sum of square & df & $\begin{array}{l}\text { Mean } \\
\text { square }\end{array}$ & F & Sig. \\
Between groups & 1745.859 & 11 & 158.714 & 39.849 & 0.000 \\
Within groups & 191.18 & 48 & 3.983 & & \\
Total & 1937.039 & 59 & & & \\
\hline
\end{tabular}


Table (4): Duncan Multiple Analysis Range Test in post hoc results of 2\% formaldehyde inhibition zones at all intervals days.

\begin{tabular}{|c|c|c|c|c|c|c|c|c|c|}
\hline \multirow{3}{*}{$\begin{array}{r}\text { Intervals } \\
\text { days } \\
\text { control }\end{array}$} & \multirow{3}{*}{$\begin{array}{l}\mathbf{N} \\
5\end{array}$} & \multirow{2}{*}{$\mathrm{A}$} & \multirow[b]{2}{*}{$\mathrm{B}$} & \multirow[b]{2}{*}{$\mathrm{C}$} & \multirow[b]{2}{*}{$\mathrm{D}$} & \multirow[b]{2}{*}{$\mathrm{E}$} & \multicolumn{3}{|c|}{ Subsets for alpha $=\mathbf{0 . 0 5}$} \\
\hline & & & & & & & $\mathrm{F}$ & $\mathrm{G}$ & $\mathrm{H}$ \\
\hline & & 0.00 & & & & & & & \\
\hline Day1 & 5 & & 34.6 & & & & & & \\
\hline Day2 & 5 & & & 24.82 & & & & & \\
\hline Day3 & 5 & & & 25.08 & & & & & \\
\hline Day4 & 5 & & & & 19.76 & & & & \\
\hline Day5 & 5 & & & & 19.34 & 19.34 & & & \\
\hline Day6 & 5 & & & & 19.46 & 19.46 & & & \\
\hline Day7 & 5 & & & & & & & 15.68 & 15.68 \\
\hline Day8 & 5 & & & & & & 16.32 & 16.32 & 16.32 \\
\hline Day9 & 5 & & & & & & & & 13.82 \\
\hline Day10 & 5 & & & & 18.82 & 18.82 & 18.82 & & \\
\hline Day11 & 5 & & & & & 16.78 & 16.78 & 16.78 & \\
\hline Day12 & 5 & & & & 17.88 & 17.88 & 17.88 & 17.88 & \\
\hline Sign. & & 1 & 1 & 0.838 & 0.192 & 0.062 & 0.075 & 0.118 & 0.066 \\
\hline
\end{tabular}

Table (5): Descriptive statistical results of $2 \%$ formaldehyde inhibition zone at all intervals days.

\begin{tabular}{lllll}
\hline Interval days & $\mathbf{N}$ & Mean & SD & SE \\
Control & 5 & 0 & 0 & 0 \\
Day 1 & 5 & 34.6 & 2.506 & 1.1207 \\
Day 2 & 5 & 24.82 & 2.584 & 1.1556 \\
Day 3 & 5 & 25.08 & 4.0709 & 1.8205 \\
Day 4 & 5 & 19.76 & 1.2818 & 0.5732 \\
Day 5 & 5 & 19.34 & 1.6349 & 0.7312 \\
Day 6 & 5 & 19.46 & 1.4135 & 0.6321 \\
Day 7 & 5 & 15.68 & 1.3554 & 0.6061 \\
Day 8 & 5 & 16.32 & 1.8116 & 0.8102 \\
Day 9 & 5 & 13.82 & 0.3347 & 0.1497 \\
Day 10 & 5 & 18.82 & 0.563 & 0.2518 \\
Day 11 & 5 & 16.78 & 2.0825 & 0.9313 \\
Day 12 & 5 & 17.88 & 1.4377 & 0.643 \\
& & & & \\
\hline
\end{tabular}


Also the results present there is a significant differences between all days comparing with day1at $\mathrm{P}<0.05$. That means the antibacterial effect results of $2 \%$ formaldehyde stone discs shows the best effect of 2\%formaldehyde against salivary bacteria at the day1 as shown in Table (5) and the effect continued randomly till day12 Figure(6).

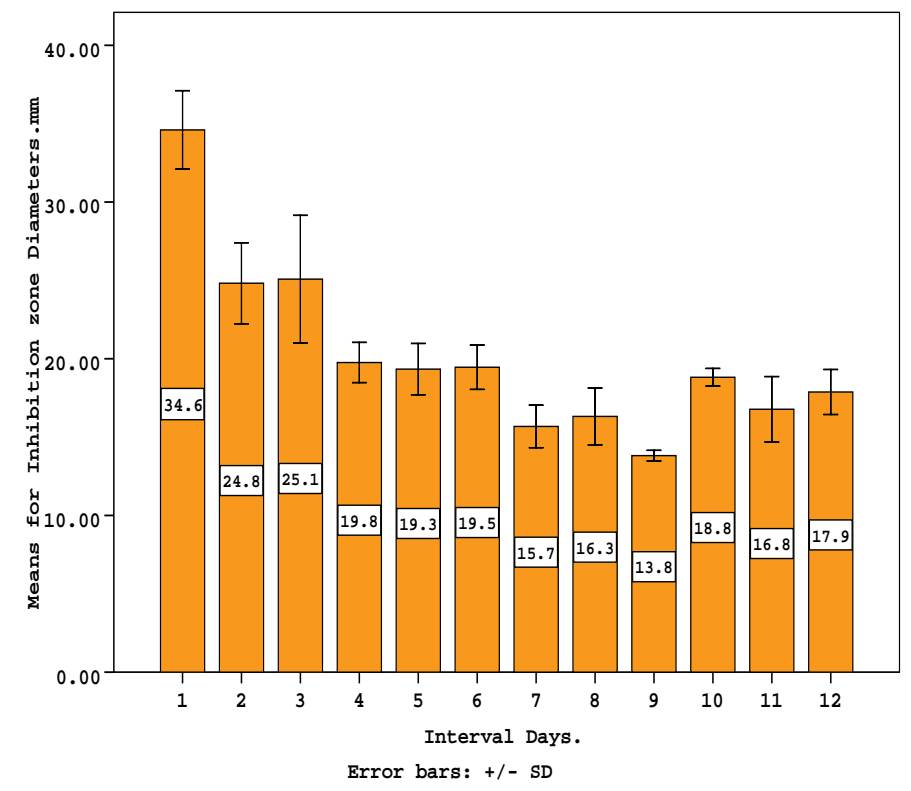

Figure (6): Means and standard deviations of 2\% formaldehyde inhibition zone diameter at different intervals.

\section{DISCUSIONS}

The results of this study agree with other studies using other disinfectant material which is like sodium hypochlorite and immersion method (immersion dental cast in disinfectant) and the compressive strength was for disinfectant group was (520.2 $\mathrm{kg} / \mathrm{cm} 2$ ) and for control was (363.6 $\mathrm{kg} / \mathrm{cm} 2)^{(17)}$.

A possible explanation for the increased compressive strength is that the disinfectant may assist or increase the adhesion between the dihydrate crystals ${ }^{(17),}$ because stone is chemically composed of Alfa calcium sulfate hemihydrate crystals these crystals are regular in shape and high density these particles react with water to form calcium sulfate dihydrate crystal ${ }^{(18) .}$

Some other chemicals like calcium oxide which act as a hardener modifier and improved the adhesive forces between particles (crystals) and there was an increase in the compressive strength of gypsum products by addition of calcium oxide ${ }^{(19) .}$

This study proved that only a small concentration of formaldehyde (2\%) was given high antibacterial activity in addition of increasing the compressive strength of dental stone (type IV).

\section{CONCLUSIONS}

Using 2\%formaldehyde disinfectant as 
water substitute additive to dental stone (type IV) significantly increasing compressive strength of dental stone (type IV) when comparing that value with control group, while the antibacterial effect, the $2 \%$ formaldehyde continuo to release till 12 th day.

\section{REFERENCES}

1. Leung RL, Schonfeld SE. Gypsum casts as a potential source of microbial crosscontamination. J Prosthet Dent. 1983; 49(2): 210-211.

2. Rowe AH, Forest JO. Dental impressions: The probability of contamination and a method of disinfection. Brit Dent J. 1978; 145: 184-186.

3. Egusa H, Watamoto T, Abe K, Kobayashi M, Kaneda Y, Ashida S, Matsumoto T, Yatani H. An analysis of the persistent presence of opportunistic pathogens on patientderived dental impressions and gypsum casts. Int J of Prosthodont. 2008; 21(1): 62-68.

4. Sofou A, Larsen T, Fiehn NE, Owall B. Contamination level of alginate impressions arriving at a dental laboratory. Clinic Oral Investig. 2002; 6(3): 161-165.

5. Craig RG, Powers JM, Wataha JC. Dental materials properties and manipulation. 8th edition. Michigan. Mosby. USA. 2004; Pp: 199, 210.

6. Twomey JO, Khalid MA, Combe EC. Calcium hypochlorite as a disinfecting additive for dental stone. J Prosthet Dent. 2003; 3: $282-288$.

7. Mazzola PG, Jozala AF, De Lencastre LC,
Moriel P, Vessoni TC. Minimal inhibitory concentration (MIC) determination of disinfectant and/or sterilizing agents. Brazilian J Pharma Sci. 2009; 45: 241-248.

8. Abdelaziz KM, Combe EC, Hodges JS. The effect of disinfectants on the properties of dental gypsum mechanical properties. J Prosthodont. 2002; 11: 161-167.

9. Breault, LG, Paul JR, Hondrum SO. Die stone disinfection: incorporation of sodium hypochlorite. J Prosthodont .1998; 1: 13-16.

10. Ivanovski S, Savage NW, Brockhurst PJ, Bird PS. Disinfection of dental stone casts: Antimicrobial effects and physical property alterations. J Dent Mater. 1995; 11: 19-23.

11. Whyte MP, Brockhurst PJ. The effect of steam sterilization on the properties of set dental gypsum models. Aust Dent J. 1996; 41(2): 128-133.

12. Schutt RW. Bactericidal effect of a disinfected dental stone on irreversible Hydrocolloid impressions and stone casts. J Prosthet Dent. 1989; 62: 605-607.

13. Davis BA, Powers SM. Effect of immersion disinfection on properties of impression materials. J Prosthodont. 1994; 3: 31-34.

14. Holtan JR, Olin PS, Rudney JD. Dimensional stability of polyvinyl-siloxane impression materials following ethylene oxide and steam autoclave sterilization. J Prosthet Dent. 1991; 65: 519-525.

15. American National Standards. American Dental Association Specification No. 25 for Dental Gypsum Products. New York. Amer- 
ican National Standards Institute. 2000; Pp: 244-253.

16. American dental association. Guide to dental materials and devices. 7th edition. Chicago. USA. 1975; P: 259.

17. Jwad Ml, Khamas AM, Al-Azzawi S. Compressive strength and surface roughness of die stone cast after repeated disinfection with sodium hypochlorite solution. Journal Baghdad College Dentistry. 2010; 22(3):

\section{7-33.}

18. Koudi MS, and Patil BS. Dental materials prep manual for undergraduates. 1st edition. Elsevier India. India. 2007; P: 48.

19. Hatim NA, Al-Khayat IK, Abdullah MA. Modification of gypsum products (Part I): physical and mechanical properties of adding some additives on different types of gypsum products. Al-Rafidain Dent J. 2007; 7(2): 206-212. 